\title{
The Urgency of Arbitration Clause in International Trade Contract of Electronic Transaction
}

\author{
Mohammad Zamroni*
}

\author{
Faculty of Law, Universitas Hang Tuah, Surabaya 60117, Indonesia \\ *Corresponding author. Email: zamroni@hangtuah.ac.id
}

\begin{abstract}
Technology of Information has shifted the type of international trade from complicated way under particular domestic and international regulations to more simple way. Electronic transaction (i.e., e-commerce), in fact, seems like denying jurisdictions that countries have. A citizen of a state may simply do a transaction with someone from another state. However, e-commerce may also bring particular problems on which the subjects are in dispute, given that it is a non-face-to-face transaction and each of the parties engaged are in different states. It will be more complicated if neither legal option nor forum is established during the contract settlement. The injured party may definitely encounter difficulties in proposing a legal action, especially on which the engaged parties are in different states. Therefore, this paper aimed to analyze the urgency of mentioning arbitration clause in international trade contract of e-commerce. It was conducted through library study using three approaches including statute, conceptual, and legal comparison approaches. The result found that mentioning arbitration clause in international trade contract of e-commerce is crucial to provide legal assurance for every engaged party when they were in dispute.
\end{abstract}

Keywords: Arbitration clause, electronic-based contract, international trade, electronic transaction

\section{INTRODUCTION}

Formal has been reported that international trade through e-commerce grows rapidly along with the development of technology of information. McKinsey argued that the development of trade through ecommerce had been increasing on its quantity involving the number of subjects, goods and services, and the value of merchandise. He predicted that the development of ecommerce might become more increasing eight times as much by 2020 [1].

The increasing growth of cross-border merchandising through e-commerce indeed brings positive impacts on international trade. Electronic transactions may open up a number of cross-border economic opportunities, ranging from better advertising and delivering local products and services to creating new business thanks to offshore outsourcing [2]. Electronic-based transaction (i.e., e-commerce) is evidently able to be a fastest media for developing international market. However, any possible risks that may happen in the implementation of e-commerce contract should be taken into account as well. Unlike conventional trades that use a standard contract and letter of credit to ensure its implementation, e-commerce is solely trust-based, especially those that engage two parties in direct way without involving another third party as host.

E-commerce that use an electronic host such as Alibaba is relatively more secure, given the third party that helps to ensure the implementation of trade contract. Nevertheless, the host is not an adjudication agent that has capacity to provide a kind of legal assurance for disputing parties (e.g., between seller and buyer). In case that a buyer claims that the item he received is different from the specification mentioned in contract while the seller claims the versa, for instance, the electronic host has very limited capacity to get involved and settle it down.

On the other hand, most e-commerce often neglects to mention a legal and forum option in their contract. Thus, when it falls out, the engaged parties may get troubles due to the absence of legal assurance. It gets more complicated when the transaction is classified into international trade in which the engaged parties are in different states that definitely have different legal system.

Considering such issue, it needs to investigate any concrete efforts to provide legal assurance in international e-commerce. Therefore, this study aimed to analyze the urgency of mentioning arbitrage clause in international e-commerce. The result expected to find a legal action that might bring legal assurance for any parties engaged in international e-commerce

\section{RESEARCH METHOD}

It is a legal study framed in a library research using three approaches including conceptual, statute, and legal comparison. It begins to collect legal materials from 
many libraries both conventional and online ones such as textbooks, e-books, articles, and journals. The collected data is then organized in systematic way and analyzed by comparing the regulations that regulate electronic-based transaction in United States. Those are Uniform Electronic Transaction Act (UETA), Act No. 19/ 2016 about the Amendment of Act No 11/ 2008 about Information and Electronic Transaction (UU ITE) applied in Indonesia, and UNCITRAL Model Law on International Commercial Arbitration. The analysis focuses on seeking for regulation of arbitration clause in International trade contract of electronic-based transaction

\section{THEORETICAL FRAMEWORK}

\subsection{International Trade}

Economic Concept (2012) defines the term 'international' as a cross-border trade. It is an activity of transferring goods and services that include capital goods from one state to another state. Generally, international trade represents a significant part of gross domestic products. Suppose that no international trade exists, many states may encounter limitation on goods and services they produce [3].

Amir Hossain defines international trade as a transfer of capital, goods, and services across international border or territory. It gives chances for consumers and states to be exposed to new products and markets. Merchandises that international markets sell are called export commodity, and what they buy are called import commodity [4].

In the preamble of UNCITRAL, it mentions that the development of international trade that relies on the principle of mutual benefits and equity is an important element to promote good relationship among countries in the world. Hence, it needs common rules that regulate international trade contract without putting aside the variety of social, economy and legal systems that every country has.

Referring to those definitions of international trade, it simply says that it is an activity of transferring equity, goods, and services across international borders based on the principle of equity and mutual benefits.

\subsection{Electronic-based Transaction}

Daniel Seng who studied electronic transaction in Singapore and Hong Kong failed to generate the definition of electronic transaction, either in Electronic Transaction Act (ETA) or Electronic Transaction Ordinance (ETO). He compared to INCITRAL Convention that used the term "electronic communication", instead of using 'electronic transaction', and it referred to online communication in the form of statement, request, notification, and offering ;including lobbying and accepting a tender which requires the engaged parties to make and/or decide to work together under particular formation or contract [5]. The term 'e-commerce' was known in the middle of 1990s on which there was the likelihood to do online commercial transactions. Lee and Phang defined electronic transaction in narrower context as goods ads and merchandising through telecommunication network recognized in e-commerce [6]. On the other hand, M. Ikhsan Lubis defines 'electronic transaction' as electronic-based merchandising transactions. He refers to the definition proposed by Julian Ding who uses the term "e-commerce." Julian Ding argues that e-commerce is a seller-buyer transaction to provide goods and services (i.e., transferring of rights). The process is through online or digital media in which both parties do not physically see to one another [7]. Using computer, computer network, and/or another electronic media. This definition is actually too general, since it defines 'transaction' as legal action which can be conducted in unilateral, bilateral, and multilateral ways. It seems more appropriate to use 'legal relationship' as the diction, given that legal relationship indicates either bilateral or multilateral transaction.

There are some models of electronic transactions including business-to-business (B2B), governmental agencies (G2G), business-to-government (B2G), business-to-consumer (B2C), and government-toconsumer (G2C).

Referring to all of those definitions, it infers that electronic transaction is a kind of legal relationship between two or more parties through electronic system.

\subsection{Electronic Contract}

Contract is defined as a legal incident through which one party promises to another party to do or not to do something [8]. Electronic contract is considered as an agreement through electronic media or technology of information and is mentioned in an electronic document or another electronic media [9]. UETA definse the term 'contract' as the total legal obligation resulting from the parties' agreement as affected by this [Act] and other applicable law. On the other hand, UU ITE formulates the definition of electronic contract in Article 1 subsection 17 mentioning that electronic contract is an agreement among parties through electronic system. In general, the process of making up to implementing a contract consists of three stages including pre-contract, closure, and implementation. The first stage, precontract, is marked by collecting information and negotiation. The second stage, closure, is marked by establishing the agreement of engaged parties. The third 
stage refers to accomplishing performance. The engaged parties have their own obligations to perform as what has been mentioned in agreement.

In addition, conventional contract always brings the engaged parties together to make agreement and sign the deed directly. In electronic contract, however, they do not need to meet each other since all the process of transaction, from creating up to implementing the contract, is through electronic system. It is also paperless and only needs electronic media and internet network. This convenience on electronic contract makes parties feel that they do not need to read the $\mathrm{T} \& \mathrm{C}$ in detail. Therefore, electronic contract is defined as an agreement between two or more parties through electronic system and media.

\section{THE REGULATION OF ELECTRONIC TRANSACTION}

Naser A. Nanehkaran argues that electronic transaction or e-commerce is one primary criteria of revolution on technology of information and communication in economy sector. The style of e-commerce is very beneficial as it has capacity to spread out quickly. It can be confirmed that e-commerce has shifted many limitations in conventional business. For instance, the types and appearance of conventional business has shifted primarily. The presence of virtual market and stores with no physical space as their stands enable access and goods circulation anywhere without requiring people to leave their house [10].

Some principles in electronic transaction involve the freedom of making contract, government interference that corresponds to internet domain, dispositive method as the priority in legal regulation, and the development of free-paid electronic transaction, as well as supporting free competition [11]. These principles are expected to be general rules and enable to give legal assurance for every engaged party that does e-commerce.

However, e-commerce, particularly to cross-border transaction, needs more attention given that it is across jurisdiction and country with no face-to-face meeting. Almost all states have rules that regulate electronic transaction, such as United States that has regulated electronic transaction since 1999 through UETA. In addition, Singapore has made regulation for electronic transaction since 1998 through The Electronic Transaction Act (ETA). Moreover, Indonesia has made regulation on electronic transaction since 2008 through UU ITE completed with Government Regulation No. 82/ 2012 about the Organization of Electronic System and Transaction (i.e., PP PSTE). Jordan, although little bit late, has made regulation for electronic transaction under Jordanian Electronic Transaction No. 15 / 2015 [12]. UETA regulates anything that deals with electronic transaction, such as an individual's single purchasing on a retailer, weekly or monthly repeat order between a big company and its business partners, individual's purchasing through online vendor, and the closure of business purchasing through fax transmission or email. UETA also requires that a transaction should involve a legal relationship between two or more parties.

On the other hand, UU ITE only provides general regulation on electronic transaction, and thus, any legal actions using computer, network, and/or another electronic media, both public and private, is seen as electronic transaction (Article 17 UU ITE).

Related to electronic contract, UU ITE asserts that electronic transaction mentioned in an electronic contract imbedded all the engaged parties. The contracting parties are free to decide what legal regulation they apply to for international electronic transaction. However, international civil law will apply if the contracting parties do not decide their legal option yet (Article 18 UU ITE).

\section{ARBITRATION CLAUSE IN ELECTRO- NIC CONTRACT}

UNCITRAL defines arbitrage as any arbitration whether or not administered by a permanent arbitral institution. On the other hand, arbitration clause refers to the term "clause compromissoire". Luis Dominguez defines arbitration clause as terms and condition (i.e., T\&C) of commercial contract through which the engaged parties agree to settle every conflict related to the agreement through arbitration. He argues that arbitration clause of international commerce enables to be designed in various ways, given that the engaged parties have enough time and space to design the agreement of arbitration [13].

Neither UU ITE nor UETA regulates arbitration clause. UU ITE only regulates the forum option in which the engaged parties have chance to decide their forum to solve conflict between them. It can be through court, arbitration, or another alternative that has authority to solve their conflict that deals with international electronic transaction. Nevertheless, it will rely on international civil law if the engaged parties have no clue on what forum option they choose for settling conflict (Article 18 UU ITE).

Indonesia recognizes the term arbitration clause, and it can be found in Act No. 30/ 1999 about Arbitration and Alternatives of Conflict Settlement (i.e., UU AAPS). It mentions that the agreement of arbitration is a clause of arbitration mentioned in a written agreement made by the contracting parties before the conflict reveals, or that it is separately made after the conflict revealed (Article 1 subsection 2 of UU AAPS). This provision seems less appropriate, given that the concept of arbitration clause differs from the concept of agreement for arbitration. The clause of arbitration can be mentioned in every contract 
and put in chapter of conflict settlement. It is intentionally mentioned to anticipate any possible conflict that may happen during the implementation of contract. The agreement of arbitration, however, is made specifically by the contracting parties to solve any conflict between them through arbitration.

Following Diana Hogas, arbitration clause should correspond to the engaged parties' conditions and needs, not aimed to solve every problem that adheres in arbitration. Indeed, it is not that easy to design arbitration clause. However, a good-designed arbitration clause may become a magic wand for the contracting parties. Quoting what John M. Townsend argued, there are seven problems that may happen in deciding arbitration clause. Those include excuse, less attention, negligence, excessive particularity, unrealistic expectation, litigation jealousy, and excessive scope [14].

On the other hand, following Luis Dominguez, to facilitate in designing arbitration clause, the contracting parties and the counselor may predict the most possible conflict sources by making adjustment that corresponds to the content of arbitration clause, although it sometimes reveals controversy due to misconception (e.g., culture and language use), force majeure, or unexpected condition.

In accordance to those all arguments, it infers that, as what has been entirely mentioned in a contract, designing and agreeing arbitration clause is not that easy since there are various interests from the engaged parties and a variety of possible problems that may happen as what John M. Townsend and Luis Dominguez argued. Conflicts can be much more complicated when the contracting parties are from different states with different legal system as well. Therefore, it needs an international consent to provide rules of arbitration clause for general application.

Designing and dealing arbitration clause is indeed complicated. Hence, the contracting parties tend to ignore this matter and focus on the contract. Unfortunately, the injured party may get big trouble when problems or conflict come during the contract implementation. The absence of arbitration clause in a contract may result in neither legal assurance nor forum for the contracting parties to propose a lawsuit. In such condition, the injured party may not be able to do any legal action but waiting for miracle such as a good faith from another party.

The principle of freedom in making contract provides widest chances to the contracting parties to decide their legal and forum options for conflict settlement. It is also a freedom to not choose any legal and forum option. Relating to the fact of cross-border transactions with no legal assurance or forum for conflict settlement, the arbitration clause is very crucial. The existence of arbitration clause in electronic transaction (i.e., ecommerce) may provide legal assurance to both contracting parties on which they encounter a legal problem during implementing their contract.

Indeed, regulations that deal with electronic transaction, such as UETA and UU ITE, do not regulate about conflict settlement through arbitration. Generally, the contracting parties are legally free to decide what legal and forum option they take for conflict settlement. Hence, to anticipate any legal conflicts that may happen during the process of contract implementation, arbitration clause should always be mentioned in electronic contract, so that the injured party has legal assurance on the forum of conflict settlement. In addition, every state's regulation should necessarily obligate the contracting parties on electronic transaction to mention arbitration clause in their electronic contract.

\section{CONCLUSION}

The existence of arbitration clause is very crucial, particularly to cross-border electronic transactions, as it provides legal assurance related to conflict settlement forum for both contracting parties on which they encounter a conflict or problem during implementing their contract. As regulator, government or international commercial organization should be able enact regulations that provide legal assurance for cross-border e-commerce by requiring the contracting parties to always mention arbitration clause in their electronic contract.

\section{ACKNOWLEDGMENT}

This research was supported by the research department of Universitas Hang Tuah Surabaya (2019) for Arbitration and ADR International Conference (ADRIC).

\section{REFERENCES}

[1]. www.cnnindonesia.com/teknologi/2019012813371 4-185-364403/6-trend-perdagangan-digital-2019

[2]. Luca G. Castellani, “The Contribution of A Uniform Legislative Framework for Electronic Transactions to Promoting Economic Development in the Pacific", CLJP-RJP, 17, 2011.

[3]. Danjuma Naisla Hassan, Habakuk Aboki and Amos Anyesha Audu, "International Trade: A Mechanism For Emerging Market Economies", International Journal of Development and Emerging Economies, Vol. 2, No. 4, pp. 24-32, December 2014.

[4]. Md. Amir Hossain, "Impact of International Relation in Trade \& Development From Bangladesh 
Perspective", Scholedge International Journal of Multidisciplinary \& Allied Studies, Vol. 2, Issue 12, 2015.

[5]. Daniel Seng, “The Singapore Electronic Transactions Act and The Hongkong Electronic Transactions Ordinance", Digital Evidence and Electronic Signature Law Review, Vol. 5, 2008.

[6]. Lee, SYT, Phang, CWD, "Leveraging Social Media for Electronic Commerce in Asia: Research Areas and Opportunities", Electronic Commerce Research and Application, 3(14), 145-149, 2015.

[7]. Muhamad Ikhsan Lubis, "Online Buying and Selling Transactions Under International Private Law", Journal of Private and Commercial Law, Volume 2, No.1, Mei 2018.

[8]. Mohammad Zamroni, "Penafsiran Kontrak dalam Perspektif Hermeneutik", Yuridika, Vol. 31 No. 3, 2016.

[9]. Rosa Agustina, "Kontrak Elektronik (E-Contract) Dalam Sistem Hukum Indonesia", Gloria Juris, 8, 2008

[10]. Yaser Ahangari Nanehkaran, "An Internation to Electronic Commerce", International Journal of Science \& Technology Research, Volume 2, Issue 4, April 2013.

[11]. Elena Anatolyevna Kirillova, et.al., "The Principles of The Consumer Right Protection in Electronic Trade: A Comparative Law Analysis", International Journal of Economics and Financial Issues, 6 (S2) 117-122, 2016.

[12]. Ali Al-Zubi and Bassam Al-Trawneh, "The Electronic Signature and The Problems od Its Practical Applicable", International Journal of Humanities and Social Science, Vol. 6, No. 12, December 2016.

[13]. Luis Alfonso Gomez Dominguez, "Causes and Consequences of Faulty Arbitration Clauses", Estud. Socio-Jurid., Bogota (Colombia), 9(2): 111141, julio-diciembre de 2007.

[14]. Diana-Loredana Hogas, "Considerations About Drafting Arbitration Clauses", Journal of Public Administrations, Finance and Law, Special Issue 2/2015. 